\title{
THE AMERICAN JOURNAL OF PSYCHIATRY
}

\section{Volume 143, Number 8}

August 1986

\author{
Presidential Papers: 1986 \\ 949 Presidential Address: Health Care Directions: Who Cares for Patients? Carol C. Nadelson \\ 955 Response to the Presidential Address: Health Care Crisis: A Campaign for Action Robert O. Pasnau \\ 959 Carol C. Nadelson, M.D., One Hundred Fourteenth President, 1985-1986 Theodore Nadelson \\ Special Articles \\ 962 The Empiricist and His New Clothes: DMS-III in Perspoctive. David Faust and Richard A. Miner \\ 968 The Clinician-Researcher in Psychiatry Jack D. Burke, Jr., Harold Alan Pincus and Herbert Pardes \\ Regular Arricles \\ 976 Correlates of Lateral Ventricular Size in Chronic Schizophrenia, I: Behavioral and Treatment Response \\ Measures Miklos F. Losonczy, I. S. Song, Richard C. Mohs, Nancy A. Small, Michael Davidson, Celeste A. \\ Johns and Kenneth L. Davis \\ 982 Comparative Psychological Disturbance in Patients With Pancreatic and Gastric Cancer Jimmie C. Holland, \\ Ann Hughes Korzun, Susan Tross, Peter Silberfarb, Michael Perry, Robert Comis and Martin Oster \\ 987 Management of Established Pathological Grief Reaction After Stillbirth John T. Condon \\ 993 Prevalence of Smoking Among Psychiatric Outpatients John R. Hughes, Dorothy K. Hatsukami, James $E$. \\ Mitchell and Lisa A. Dahlgren \\ 998 An Examination of the Borderline Diagnosis in Children Deborah A. Greenman, John G. Gunderson \\ Melanie Cane and Peter R. Salzman \\ 1004 Right-Hemisphere Deficit Syndrome in Children Kytja K. S. Voeller \\ 1010 Diagnostic Pattern for Neuroses in China, Japan, and the United States Wen-Shing Tseng, Xu Di, Keisuke \\ Ebata, Jing Hsu and Cui Yuhua \\ Commentary \\ 1015 Health Care: For Patients or for Profits? Leon Eisenberg \\ Brief Communications \\ 1020 Clinicians' Guidelines for Assessing and Presenting Subtle Forms of Patient Incompetence in Legal Settings \\ Thomas G. Gutheil and Harold Bursztajn \\ 1024 Assessment of Depression in Childhood and Adolescence: An Evaluation of the Center for Epidemiological \\ Studies Depression Scale for Children (DES-DC) Michael E. Faulstich, Michael P. Carey, Laurie Ruggiero, \\ Patience Enyart and Frank Gresham \\ 1027 Malignant Hyperthermia and ECT Odile F. Yacoub and Dean H. Morrow \\ 1030 ECT Response in Depressed Patients With and Without a DSM-III Personality Disorder Mark \\ Zimmerman, William Coryell, Bruce Pfohl, Caryn Corenthal and Dalene Stangl \\ Clinical and Research Reports \\ 1033 Life Events and Course of Illness in Patients with Panic Disorder Peter R. Roy-Byrme. Marilla Geraci and \\ Thomas W. Uhde \\ 1035 Phototherapy for Seasonal Affective Disorder in Alaska Carla J. Hellekson, Judith A. Kline and Norman E. \\ Rosenthal \\ 1038 Lithium Potentiation of Tricyclic Antidepressants Following Lack of $\mathrm{T}_{3}$ Potentiation James C. Garbutt, \\ James P. Mayo Jr., Gregory M. Gillette, Karley Y. Little and George A. Mason \\ 1040 Generalization of the Effects of Unilateral and Bilateral ECT Conrad M. Swartz and Gunnar Larson \\ 1042 Psychosocial Characteristics of 'Double Depression' Ivan W. Miller. William H. Norman and Michael G. \\ Dow
}




\title{
The Retreat, York for Psychiatric Illnesses
}

\begin{abstract}
Founded in 1792 by the Quaker. William Tuke, who established the tradition of concern for patients as individuals The Retreat is a 200-bedded private registered nursing home surrounded by extensive grounds on the outskirts of the historic City of York. It is easily reached by rail and motorways.
\end{abstract}

Care and treatment is offered for all types of psychiatric illness on the short or long term in a sympathetic and friendly atmosphere. Patients suffering from neuroses, psychoses, alcoholism and dementia are treated by the full-time consultant psychiatrists in surroundings suitable for their individual needs. Outpatient facilities are available by appointment with the consultant medical staff.

The Nursing Home is a registered charity and is able to offer inclusive care in shared accommodation from $£ 32.00$ per day or in single rooms at slightly increased charge. The Nursing Home is recognised by the main private patient schemes.

For further details apply to The Medical Director, The Retreat, York YO1 5BN (Telephone 0904 412551).

\section{Index to Advertisers}

Pharmaceuticals

The Boots Company plc ........... facing $\mathrm{p} 353$

Brocades Limited . .................. p ii

Janssen Pharmaceutical Limited ...... facing $\mathrm{p} 365$

Lundbeck Limited ........ facing pp 365 and 366

May \& Baker Limited ............. facing p 352

E. R. Squibb Limited ....... facing pp 356 and 357

Booksellers and Publishers

Springer-Verlag $\ldots \ldots \ldots \ldots \ldots \ldots \ldots \ldots$ p vii

Universal Psychology Publishers......... p iii

\section{Clinics, Hospitals and Nursing Homes}

Bowden House Clinic.$\ldots \ldots \ldots \ldots \ldots \ldots$ p viii Charter Clinics . . . . . . . . . . . . . p vi

Ticehurst House Hospital . . . . . . . . . . . p ii

The Retreat ............... inside back cover

Appointments

Health Department Victoria ............ p v

Lord Chancellor's Department .......... p iv

Miscellaneous

Charing Cross \& Westminster

Medical School ................ pp ii and iv

West Midlands Institute of Psychotherapy .... p iv 